\title{
Г. Кадирова
}

Ташкентский государственный университет востоковедения, Узбекистан, г. Ташкент, e-mail: guzal.kadirova.1986@mail.ru

\section{ПОАИТИЧЕСКИЕ ПРОЦЕССЫ В ЕГИПТЕ В ПЕРИОА ПРАВАЕНИЯ «БРАТЬЕВ-МУСУАЬМАН»}

Статья посвящена периоду правления «Братьев-мусульман» в Египте в 2012-2013 гг. Правление президента Мухаммада Мурси, являвшегося одним из лидеров «Братьев-мусульман», было относительно неАолгим, но весьма насыщенным. В своем политическом курсе М. Мурси обычно руководствовался больше интересами организации «Братьев-мусульман», чем египетского общества или национальными интересами страны, что, естественно, отразилось на принятой в 2012 году Конституции. Аанное положение привело к углублению социально-политического и экономического кризиса и развитию нового витка внутреннего конфликта в АРЕ. Нарастающие кризисные явления в египетском обществе носили комплексный характер и, как представляется, заключались в потере М. Мурси и «Братьями-мусульманами» значительной части общественной подАержки, противодействие государственного аппарата и сил безопасности перестраиванию политической системы в духе идей Авижения «Братьев-мусульман», противостояние светской оппозиции, нарастание протестов, центром которых вновь, как и в 2011 году, стала площаАь Тахрир в Каире, а также рост доверия к армии и ее особое положение в государстве и обществе. Помимо всего, М. Мурси оказался неспособен решить социальные и экономические проблемы, а вместо этого попытался сосредоточить всю власть в своих руках. Анализ позволил заключить, что во внешней политике М. Мурси продемонстрирова^ слабое понимание национальных интересов, региональных и глобальных процессов, однако проводил больше курс, характерный скорее Аля руководителя «Братьев-мусульман», а не самой Арабской Республики Египет. Таким образом, годичное правление Братьев-мусульман привело к низвержению М. Мурси и установлению военной диктатуры в стране.

Кмючевые слова: парламентские выборы, М. Мурси, новая Конституция Египта, контрреволюционное сопротивление», массовые отставки.

\section{Г. Кадирова \\ Ташкент мемлекеттік шығыстану университеті, Өзбекстан, Ташкент к., e-mail: guzal.kadirova.1986@mail.ru \\ Египеттегі «Мұсымман бауырлар» кезеңіндегі саяси процестер}

Мақалада 2012-2013 жылдардағы Египеттегі «Мұсылман бауырлар» билігі кезеңіне арналған. «Мұсылман бауырлар» ^илерлерінің бірі болған презилент Мухаммад Мурсидің билігі біршама қысқа, бірақ өте оқиғалы болды. М. Мурси өзінің саяси бағыты бойынша 2012 жылы қабылданған Конституцияда көрініс тапқан Египет қоғамы немесе елдің ұлттық мүдлелерінен гөрі «Мұсылман бауырлар» ұйымының мүдлелерін көбірек басшылыққа а^ды. Бұл жағдай Египеттегі қоғамдықсаяси және экономикалық дағдарыстың тереңдеуіне және ішкі қақтығыстардың жаңа кезеңінің дамуына әкелді. Египет қоғамындағы өсіп келе жатқан дағдарыстық құбылыстар күрделі сипатқа ие болды және М. Мурси мен «Мұсылман бауырлар» қоғамдық қолдауының едәуір бөлігінен айырылудан, мемлекеттік аппарат пен қауіпсіздік күштерінің саяси жүйені «Мұсылман бауырлар» қозғалысының, оппозицияның рухында қайта құруға қарсы тұруы болды. Зайырлы оппозиция, наразылықтардың өсуі, оның орталығы, 2011 ж. сияқты Каирдегі Тахрир алаңы, сонымен қатар армияға деген сенім мен оның мемлекет пен қоғамдағы ерекше позициясы болды. Сонымен қатар, М. Мурси әлеуметтік-экономикалық мәселелерді шеше алмады, оның орнына барлық билікті өзінің қолына шоғырландыруға тырысты. Жүргізілген талдау сыртқы саясатта М. Мурси ұлттық мүдлелерді, аймақтық және жаһандық процестерді нашар түсінетіндігін көрсетті, ол Египет Араб республикасынан гөрі, мұсылман бауырластықтың көсеміне тиісті іс-әрекет жасады. Осылайша, «Мұсылман бауырлар» ұйымының бір жылдық билігі М. Мурсидің құлдырауына және елде әскери диктатураның орнауына әкелді.

Түйін сөздер: парламенттік сайлау, М. Мурси, Египеттің жаңа Конституциясы, контрревомюцияға қарсылық, жаппай отставкалар. 


\section{G. Kadirova \\ Tashkent State University of Oriental Studies, Uzbekistan, Tashkent, e-mail: guzal.kadirova.1986 @mail.ru \\ Political processes in Egypt during the reign of the Muslim Brotherhood}

The author's article is devoted to the period of the Muslim Brotherhood's rule in Egypt in 20122013. The reign of President Muhammad Mursi, who was one of the leaders of the Muslim Brotherhood, was relatively short, but very eventful. In his political course, $M$. Mursi was usually guided more by the interests of the Muslim Brotherhood organization than the Egyptian society or the national interests of the country, which, naturally, was reflected in the Constitution adopted in 2012. This situation led to the deepening of the socio-political and economic crisis and the development of a new round of internal conflict in Egypt. The growing crisis phenomena in Egyptian society were of a complex nature and, it seems, consisted in the loss of a significant part of public support by M. Mursi and the Muslim Brotherhood, opposition of the state apparatus and security forces to rebuilding the political system in the spirit of the ideas of the Muslim Brotherhood movement, opposition secular opposition, the growth of protests, the center of which again, as in 2011, was the Tahrir Square in Cairo, as well as the growth of confidence in the army and its special position in the state and society. In addition, M. Mursi was unable to solve social and economic problems, and instead tried to concentrate all power in his hands. The analysis made it possible to conclude that in foreign policy M. Mursi demonstrated a poor understanding of national interests, regional and global processes, but he pursued a course more characteristic of the leader of the Muslim Brotherhood, rather than the Arab Republic of Egypt itself. Thus, the one-year rule of the Muslim Brotherhood led to the overthrow of M. Mursi and the establishment of a military dictatorship in the country.

Key words: parliamentary elections, M. Morsi, new Egyptian Constitution, counter-revolutionary resistance, mass resignations.

\section{Введение}

Правление «Братьев-мусульман» было вехой в истории современного Египта. Выход движения на авансцену политической жизни произошел очень быстро, еще в разгар уличных протестов в январе 2011 года. Переходный период после отставки X. Мубарака стал временем легитимации «Братьев-мусульман» как главной политической силы страны.

Принятие в марте 2011 года новой Конституции Арабской Республики Египет создавало основы для проведения парламентских и президентских выборов и перехода власти от военного к гражданскому правительству.

Усиление влияния исламистов стало характерной тенденцией переходного периода. Так, в ходе парламентских выборов, проходивших с ноября 2011 по январь 2012 года, обнаружился перевес исламистских организаций во главе с «Братьями-мусульманами».

Выборы проводились по смешанной системе, две трети мест избирались по партийным спискам, а одна треть - по одномандатным округам. Особенностью ситуации было то, что десять депутатов напрямую назначались Высшим советом Вооруженных сил.

Наибольшее количество избирателей поддержало «Партию свободы и справедливости», созданную «Братьями-мусульманами». В общей сложности ей досталось 235 депутатских мест, или $47,2 \%$. Из них $38 \%$ мест было получено на партийных выборах.

Более радикальная салафитская партия «Аль-Нур» получила 121 место, или 24,3\%. Исламисты, таким образом, вместе получили свыше $70 \%$ мест в нижней палате парламента.

Оставшиеся позиции заняли партии «Новый Вафд» (38 мест, или 7,6\%), «Египетский блок» (34 места, или 6,8\%), «Аль-Васат» (10 мест, или 2,0\%), «Партия реформ и развития» (9 мест, или 1,8\%), «Партия Революция продолжается» (7 мест, или $1,4 \%)$, другие партии (18 мест, или 3,6\%), независимые депутаты (26 мест, или 5,2\%) (9).

«Партия свободы и справедливости» объявила о том, что спикером нижней палаты парламента будет один из лидеров «Братьев-мусульман» Мухаммад Саад аль-Кататни. В прежнем парламенте он числился независимым депутатом, формально не относившимся ни к одной из партий, поскольку «Братья-мусульмане» находились под запретом при X. Мубараке.

Наблюдатели отмечали единство «Партии свободы и справедливости» в избирательной кампании. Не было признаков внутренних расколов, которые наблюдались в период протестов, когда часть «Братьев-мусульман» выступила за переговоры с правительством $\mathrm{X}$. Мубарака, в то время как другая часть последовательно отстаивала жесткую непримиримую 
позицию немедленной отставки президента как условия переговоров или урегулирования.

Хотя исламисты одержали убедительную победу на парламентских выборах, это не означало их прихода к власти. Военные по-прежнему руководили страной, а депутаты не могли влиять ни на Высший совет Вооруженных сил, ни на будущие президентские выборы, ни на будущее правительство, поскольку именно президент назначал кабинет министров. Скорее, парламентские выборы подчеркнули популярность исламистов в обществе и их будущие намерения в отношении президентской должности.

\section{Методы исследования}

Исследование проводилось посредством теоретического, исторического и сравнительного анализа. Методологическая основа трактовки религии как философского, политическо-социокультурного феномена теоретически реализована в области религии.

\section{Основная часть}

Как отметил эксперт Фонда Карнеги Н. Браун, победив на парламентских выборах, «Братьямусульмане» оказались лицом к лицу с военными правителями, которые сохраняли постоянную наблюдательную роль для себя и были освобождены от гражданского надзора. Их вероятное соперничество, казалось, поставило «Братьевмусульман» в невыгодное положение. С одной стороны, парламент имел крайне ограниченные полномочия, с другой, светские гражданские политические силы могли поддержать не исламистов, а военных, поскольку для них военное правление могло оказаться предпочтительнее исламистского (19).

К тому же, сохранялись, хотя и не проявлялись в острой форме, расхождения между «Братьями-мусульманами» и салафитами в парламенте. Отчасти это объяснялось тем, что в конечном итоге «Партия свободы и справедливости» была больше сосредоточена на других сферах. Тем не менее, различия оставались, поскольку салафиты считают, что общество должно строго придерживаться религиозных текстов и было сосредоточено на соблюдении правил праведного поведения личности; в их глазах «Братьямусульмане» выступали, прежде всего, как политики. «Братья-мусульмане» же полагали, что салафиты больше привержены букве, а не духу ислама, а себя считали более вовлеченными в общество в целом, и поэтому достаточно гибкими в интерпретации религиозных ограничений (19).
Таким образом, «Братья-мусульмане» оказались вынужденными лавировать между светским военным руководством, светскими гражданскими силами и радикальными исламистами, представленными в парламенте партией «АльНур».

Президентские выборы состоялись в маеиюне 2012 года, и в соответствии с ранее достигнутыми договоренностями к 30 июня власть должна была полностью перейти к гражданскому правительству.

Вместе с тем, на фоне проходивших выборов президента Арабской Республики Египет Конституционный суд страны вынес решение о неконституционности избрания нижней палаты парламента. Конституционный суд признал зафиксированный в законе принцип мажоритарной избирательной системы, согласно которому на места независимых депутатов могли претендовать и представители политических партий, незаконным. Соответственно, нижняя палата парламента должна была быть распущена (3).

В ответ представители «Братьев-мусульман» подчеркнули, что в случае роспуска нижней палаты парламента у избранного президента не будет ни Основного закона, ни законодательной ветви власти (14).

Одновременно суд разрешил вышедшему во второй тур голосования наряду с лидером «Братьев-мусульман» Мухаммеду Мурси бывшему министру при X. Мубараке Ахмеду Шафику участвовать на президентских выборах. Ранее был принят закон, согласно которому бывшие соратники Х. Мубарака были исключены из политической жизни, однако Конституционный суд признал этот закон не соответствующим Основному закону страны (14).

Высший совет Вооруженных сил поддержал решения Конституционного суда, и нижняя палата парламента была распущена. Одновременно он принял на себя полномочия нижней палаты парламента, а новыми дополнениями к Конституции существенно расширял свои полномочия.

В частности, без согласия главы Высшего совета Вооруженных сил Мухаммеда Тантави президент не имел право объявлять войну. Он же сохранял полный контроль над Вооруженными силами. В Конституционном собрании, занимавшимся разработкой новой конституции, которая должна сменить конституцию переходного периода, принятую на референдуме в мае 2012 года, Высший совет Вооруженных сил получал право вето, и любая часть будущего основного закона страны не могла быть принята без их согласия (7). 
Египетский политолог Хамади аль-Ауни отмечал, что военные и «Братья-мусульмане» стали главными конкурирующими силами в Египте и боролись между собой за власть (4).

Согласно оценкам Центра Картера (США), принятые Высшим советом Вооруженных сил решения обозначили «двусмысленность» роли армии в переходный и последующий за ним период, а также резко снизили роль президента (23).

После победы на президентских выборах лидер «Братьев-мусульман» М. Мурси предпринял настойчивые попытки утвердить свою власть как главы государства.

В частности, он почти сразу же выпустил постановление, согласно которому распущенная решением Конституционного суда нижняя палата парламента должна быть созвана и заседать до проведения новых парламентских выборов. В ответ Конституционный суд вынес новое решение, которое подтверждало незаконность результатов выборов и тем самым отменяло постановление президента.

Данный инцидент свидетельствует о том, что президентские выборы и избрание М. Мурси не принесли стабильности в политическую систему страны. Новый президент столкнулся с судебной властью, военные по-прежнему контролировали значительную часть политических процессов, парламент был представлен только верхней палатой. К тому же, сильны были протестные настроения светской части «революционеров».

В августе 2012 года М. Мурси сместил руководство Вооруженными силами (11), лишил основных полномочий Высший совет вооруженных сил, а затем предпринял попытку изменить конституционный строй страны в направлении усиления президентской власти и реализации идеологических установок «Братьев-мусульман».

Важнейшим шагом в данном направлении стала работа конституционной ассамблеи, фактически завершившейся после конституционного декрета президента Египта от 22 ноября 2012 года. Декрет запрещал Конституционному суду оспаривать решения главы государства. Это спровоцировало открытый конфликт между исполнительной и судебной властью. В ответ на конституционный декрет президента египетские судьи объявили забастовку. Одновременно возобновились уличные протесты населения. Протестующие обвиняли действующего президента в установлении диктатуры.

Всего несколько дней спустя после опубликования конституционного декрета был одобрен проект новой Конституции Египта и объявлено о референдуме, который прошел 15 и 22 декабря 2012 года. Проект конституции Египта был одобрен $63,8 \%$ голосов (22).

Однако референдум проходил на фоне нарастающих протестов оппозиции, которая обвиняла «Братьев-мусульман» в подтасовке результатов. Кроме того, новая Конституция Египта вызвала широкое недовольство разных социальных групп - от религиозных меньшинств, которые считали ущемляющими их права принципы шариата, указанные в Основном законе, до светской оппозиции, которая обвиняла «Братьев-мусульман» в исламизации, а президента - в диктаторских замашках и намерении стать «новым фараоном» (9).

Текст Конституции Египта закреплял положение президента как главного действующего лица на политической арене страны. Согласно статье 132, он являлся «Главой Государства и исполнительной власти» (8).

Вместе с тем, Основной закон вызвал дискуссии по целому ряду направлений. В частности, статья 2 закрепляла статус ислама как государственной религии, а шариат - как источник законодательства. Статья 4 существенно расширяла права Аль-Азхар, мнение «высших ученых» которого необходимо запрашивать по вопросам, связанным с шариатом. Однако механизмы консультирования прописаны не были, а объявленная «независимость» сдерживалась фактом дальнейшего законодательного регулирования основных положений, связанных с его деятельностью.

Согласно статье 10 , семья основана на «религии, морали и патриотизме», а «государство стремится сохранить подлинный характер египетской семьи, ее сплоченность и стабильность, а также защитить ее моральные ценности в соответствии с законом» (8).

При этом критики подвергали сомнению термин «подлинность» характера египетской семьи, а также недостаточные гарантии для женщин, в то время как сторонники утверждали, что неопределенность терминологии едва ли станет препятствием, поскольку положение семьи будет регулироваться другими нормативно-правовыми актами.

Статья 11, провозглашавшая обязанность государства по защите общественной морали, могла быть под этим предлогом интерпретирована для ущемления личных прав и свобод, в то время как в прежней редакции использовалась более расплывчатая формулировка «общество», а не «государство». 
Статья 43 фактически ограничивала религиозную свободу тремя «божественными» религиями - исламом, христианством и иудаизмом. Это ставило последователей других религиозных течений в бесправное положение.

Статья 44 о запрещении оскорбления любых религиозных посланников или пророков не столько гарантировала права верующих, сколько служила средством ограничения других прав и свобод в силу неопределенности того, в чем именно заключалось оскорбление, и какой орган должен выносить решение по данному вопросу.

Статья 219 ограничивала принципы исламского шариата суннитскими доктринами. Это, как отмечали эксперты фонда Карнеги, не просто отвергало шиизм, но и, возможно, создавало основу для более радикального исламистского законодательства в будущем (20).

Роль военных в Основном законе была обозначена в статье 197, где говорилось о Совете национальной обороны, который отвечал за вопросы, «связанные с методами обеспечения безопасности страны и бюджетом Вооруженных сил. Мнение совета запрашивается при разработке законопроектов, связанных с Вооруженными силами. Другие компетенции должны определяться законом» (8).

Совет национальный обороны представляется структурой, которая поставила силы безопасности и связанные с ними структуры и предприятия выше закона. Совет фактически единолично контролировал военный бюджет и имел достаточно расплывчатые границы полномочий касательно законопроектов или законодательной власти.

По мнению экспертов фонда Карнеги, статья 169 Основного закона ограничивала роль судебной ветви власти в пользу законодательной, позволяя законодательной ветви власти принимать нормативно-правовые акты, касавшиеся деятельности судебных органов, в то время как статья 176, уменьшавшая число судей Верховного конституционного суда с 19 до 11, не только суживала возможность более широкого и объективного обсуждения, но и исключала несогласных с исламистами, поскольку все восемь ушедших судей были их противниками (20).

В целом, принятие новой конституции Египта закрепило статус президента, однако было неоднозначным и способствовало нарастанию протестного потенциала.

После вступления в силу новой Конституции 21 февраля 2013 года был принят новый закон о выборах, и М. Мурси принял решение прове- сти парламентские выборы в апреле 2013 года. Однако Административный суд Египта отменил это решение, основываясь на том, что Конституционный суд еще не рассмотрел легитимность нового закона о выборах (1).

Противостояние М. Мурси и судебной ветви власти происходило на фоне не прекращавшихся протестов и падения популярности нового режима, который обвиняли в неспособности решить основные проблемы, стоявшие перед обществом и страной в период выступлений против X. Мубарака, утверждении новой диктатуры, а также в проведении исламизации и подмене египетских ценностей ценностями «Братьев-мусульман».

В этих условиях М. Мурси должен был предпринять шаги, которые стабилизировали бы внутриполитическое положение, наладили взаимодействие с другими ведущими политическими силами, а также упрочили международное положение Египта.

Однако проблемы, стоящие перед Египтом, будь то внутренние или внешние, лишь усугублялись. Несмотря на то, что М. Мурси формально покинул ряды «Братьев-мусульман», он, прежде всего, представлял их интересы, а не интересы Египта, во главе государства.

Еще до избрания М. Мурси во внутренней политике наметились тенденции ограничения свободы слова. Осенью 2011 года появились сообщения об арестах и задержаниях граждан Египта за те или иные публикации или выступления. Аресты отражали влияние двух доминирующих сил египетской политики, исламистов и армии. Так, в октябре 2011 года один из блогеров был арестован и приговорен в гражданском суде к трем годам заключения за «неуважение к религии», выразив в блоге «неблагоприятное» мнение об исламе. Ряд активистов и блогеров были заключены в тюрьму и преданы военному суду по обвинению в «оскорблении армии», в том числе за жалобы на недемократический характер военного правления (25).

После президентских выборов М. Мурси столкнулся с необходимостью считаться с мнениями, отличающимися от его собственного. В частности, он вынужден был учитывать точку зрения религиозных деятелей университета АльАзхар. «Братья-мусульмане» не могли утверждать египетскому обществу, что является или не является исламским, не подвергаясь критике со стороны широкого круга религиозных деятелей самого престижного учебного заведения страны.

Однако наибольшим препятствием для М. Мурси стали экономические реалии. Экономика 
Египта переживала тяжелый кризис. Стабильность и, следовательно, демократические изменения в Египте зависели во многом от того, как развивалась экономика. Туризм и инвестиции находились в упадке, а безработица среди молодежи колебалась на уровне около $25 \%$.

Российский эксперт М. Ражбадинов утверждал, «Братья-мусульмане» «не выступают против модернизации как таковой, они лишь предлагают отказаться от форсированных или агрессивных попыток модернизации исламского мира и двигаться по пути реформ осторожно, соблюдая середину между консервативным и модернистским началом, традицией и прогрессом. В такой постановке тезиса «Братья-мусульмане» выражают интересы той части консервативно мыслящего среднего класса и интеллигенции, которая ориентируется на умеренную демократизацию мусульманских обществ, проведение постепенных политических и социальных реформ на основе религиозных ценностей» (12).

Однако М. Мурси не имел ясной экономической программы по выводу страны из кризиса. К тому же, столкновения экономических интересов исламистов и армии наблюдались так же очевидно, как и в политической сфере.

Как отмечал эксперт Лондонской школы экономики Э. Стейн, армия имела доступ к наиболее выгодным ресурсоемким отраслям, таким как транспорт, тяжелая промышленность, нефть и газ, очистка сточных вод и производство продуктов питания. Ее интересы присутствовали в совместных предприятиях с участием иностранного капитала.

В свою очередь, «Братья-мусульмане» объединяли состоятельных бизнесменов в сфере торговли и услуг, а также в финансовом секторе. Они были активно заинтересованы в иностранных инвестициях, и в этих целях была создана Ассоциация бизнеса и инвестиций, чтобы облегчить привлечение иностранного капитала (26).

Неспособность М. Мурси решить внутриполитические и экономические проблемы, попытки исламизации политической системы и общества по образцу «Братьев-мусульман», сосредоточение исключительных полномочий в собственных руках привели к возобновлению уличных протестов, которые впоследствии обернулись столкновениями и жертвами, что, в конечном итоге, подорвало его власть.

Во внешней политике период президентства М. Мурси характеризовался преимущественно неудачами и нарастающими проблемами. Как отмечал египетский эксперт А. Эльхадиди,
М. Мурси не очень хорошо понимал национальные интересы Египта и не знал ни регион, ни окружающий мир (18). Другой исследователь, А. Эль-Адави, добавлял, что последствия этого для президента М. Мурси и проводимого им курса были «катастрофическими» (17).

После революции 2011 года иностранные дела отошли на второй план перед необходимостью решения внутренних проблем. В период между свержением X. Мубарака и президентством М. Мурси лишь в одном случае, в марте 2011 года, бывший министр иностранных дел, а затем Генеральный секретарь Лиги арабских государств Набиль аль-Араби выступил с инициативой нормализации отношений с Ираном, с которым связи были разорваны в 1979 году, но эта идея не получила развития.

После прихода к власти М. Мурси фактически отстранил Министерство иностранных дел от проведения внешнеполитического курса, сведя его роль к сугубо технической.

В прошлом подобные шаги вели к усилению иных центров принятия решений, прежде всего сил безопасности. Так, еще при президенте А. Садате в 1977 году И. Фахми подал в отставку с поста министра иностранных дел в знак протеста против египетской мирной инициативы в отношении Израиля. Отставка преемника И. Фахми, М. Камеля, в конечном итоге вынудила А. Садата больше зависеть от других ветвей власти, особенно от органов безопасности, в решении вопросов внешней политики.

При Х. Мубараке роль министерства иностранных дел сохранилась, однако к концу правления постепенно возросла. Министр иностранных дел А. Гейт добился некоторого увеличения полномочий, однако это происходило за счет наращивания сотрудничества с органами безопасности.

В политике, осуществляемой М. Мурси, появились признаки того, что президент страны отдавал приоритет организационным интересам «Братьев-мусульман» перед интересами государства, в том числе путем пересмотра приоритетов национальной безопасности. Это вызвало столкновения с аппаратом государственной безопасности и системой государственного управления, ответственной за реализацию внешней политики (17).

Министерство иностранных дел АРЕ выполняло роль обслуживания и реализации внешнеполитических решений, формулируемых главой государства. Министр иностранных дел Мухаммед Камель Амр принял ту номинальную роль, 
которую играло его министерство. Когда, например, М. Мурси предпринял беспрецедентный шаг, отозвав послов Египта из Рима и Нью-Йорка без причины и без соблюдения обязательных институциональных норм и процедур, глава МИД не стал отстаивать установленные уставы государственных учреждений или ставить под сомнение необходимость такого шага, несмотря на начавшееся брожение в среде высокопоставленных дипломатов.

Роль министерства иностранных дел Египта стала выполнять параллельная структура, возглавляемая советником М. Мурси по внешней политике Эссамом аль-Хаддадом, который зачастую действовал в качестве фактического министра иностранных дел (17).

Исключение президентом установленных государственных институтов и опытных политиков в пользу представителей «Братьев-мусульман» привело к тому, что внешняя политика стала импульсивной, внутренне противоречивой, непредсказуемой и трудной для понимания.

Прежде всего, следует отметить наметившиеся сдвиги в отношениях с США и Израилем. Хотя президент М. Мурси не предпринял каких-либо серьезных мер, которые напрямую повлияли бы на связи с Соединенными Штатами или еврейским государством в ближайшей перспективе, он стал делать шаги, которые неизбежно привели бы к радикальному изменению внешнеполитической ориентации Египта. Еще до избрания на пост президента, в условиях исламистского большинства в парламенте и на фоне протестов против сотрудничества с еврейским государством, в апреле 2012 года Египет объявил об аннулировании договора о поставках газа в Израиль (13).

Исторически тесное сотрудничество «Братьев-мусульман» с ХАМАC, особенно в отношении контрабандных поставок в сектор Газа, получило свое развитие и обретало все более четкие очертания негативных долгосрочных последствий, как для национальной безопасности Египта, так и для отношений с Израилем (17).

Первоначально администрация Б. Обамы поддержала революцию и избрание президента-исламиста, полагая, что наличие умеренного исламистского режима в Египте, как и в Турции при Реджепе Тайипе Эрдогане, лучше всего послужит интересам Вашингтона, и имея в виду имевшиеся альтернативы в египетском политическом истэблишменте.

Тем не менее, несмотря на первоначальную поддержку со стороны Вашингтона, «Братья-му- сульмане» проводили противоречивую политику, которую Б. Обама затем описал как «ни дружескую, ни враждебную», что казалось отходом от «особых отношений», сложившихся в течение большей части президентства X. Мубарака (17).

Неудачная попытка получения кредита в размере 4,8 млрд. долл. США от Международного валютного фонда, которую инициировал М. Мурси, а затем оказался не способен провести необходимые экономические реформы как условие получения кредита, выглядела еще одним подтверждением неудач его президентства.

М. Мурси попытался возобновить отношения с Исламской Республикой Иран. Одним из первых шагов стал его визит в Тегеран в августе 2012 года. Этот шаг вызвал негативную реакцию арабских государств Персидского залива, за исключением Катара.

Тем не менее, в сентябре 2012 года в знак возобновления отношений было объявлено о начале гражданских авиаперелетов между Каиром и Тегераном. Этот шаг вызвал недовольство уже внутри страны, что привело к приостановке полетов.

В феврале 2013 года в Каир прибыл с трехдневным ответным визитом в то время президент Ирана Махмуд Ахмадинежад. 31 мая 2013 года М. Мурси призвал возобновить полеты, и 132 иранских туриста прибыли в Асуан в рамках двустороннего туристического соглашения. На этот раз к возражениям со стороны силовиков присоединились уличные протесты салафитов.

Между тем, улучшение отношений с Ираном вызвало обратную реакцию в арабском мире. Так, сильно пострадали связи между Египтом и Объединенными Арабскими Эмиратами, а в 2013 году одиннадцать членов египетских «Братьев-мусульман» были задержаны в Эмиратах по обвинению в террористической деятельности. Об ухудшении отношений с Саудовской Аравией говорило то, что посол КСА в АРЕ неоднократно отзывался на родину. Король Иордании назвал М. Мурси «не имеющим глубины» понимания сложных вопросов в регионе (17).

На внешних рынках интересы армии и «Братьев-мусульман» в привлечении иностранных инвестиций наталкивались на «контрреволюционное сопротивление» со стороны традиционных источников поступления средств. Саудовская Аравия и ее союзники из числа арабских монархий Персидского залива косвенно обуславливали свою финансовую поддержку обязательством со стороны военных и исламистов Египта не экспортировать революцию за рубеж и проти- 
водействовать, сопротивляться революционным изменениям у себя в стране.

Помимо опасений перед распространением революции, идеологически Эр-Рияд был ближе к салафитам, чем к более умеренным «Братьяммусульманам». Салафиты рассматривались как возможный противовес и альтернатива «Братьям-мусульманам», хотя они и не были достаточно едины и гибки, как рассчитывала Саудовская Аравия и ее союзники.

Кроме того, арабские монархии Персидского залива опасались, что их инвестиции и закрепленные в период X. Мубарака приватизационные сделки могут оказаться под угрозой из-за популизма оппозиционных сил и стоящих у власти «Братьев-мусульман».

В отношениях с резко усилившей свое влияние на Ближнем Востоке Россией М. Мурси также показал себя недальновидным и противоречивым политиком. Он заявил о стремлении установить стратегические отношения с Москвой, что было позитивно встречено руководством Российской Федерации. Президент России В. Путин выразил надежду, что «многоплановый диалог между Россией и Египтом будет и далее углубляться, и расширяться на благо народов обоих государств, в интересах мира и стабильности на Ближнем Востоке и в Северной Африке» (6).

Однако надежды на установление стратегически значимых отношений не оправдались. Есть мнение, что все контакты и инициативы Каира, направленные на сближение двух стран, «были обусловлены лишь стремлением Каира маневрировать в отношениях с Вашингтоном и сбалансировать свою внешнюю политику в целом, а реальной заинтересованности в укреплении отношений с Москвой у Каира не было». Кремль отмечал, что Каир «продолжает ориентироваться на США и двигаться в их фарватере» (10).

На встрече в рамках БРИКС в 2013 году президент Египта выразил необычное предложение главе РФ: «открыть новую страницу в наших отношениях в том, что касается газовой сферы, в частности поставок египетского газа в Россию» (4). Подобная идея, как представляется, была вполне в духе руководства Египта, которое слабо представляло региональную и глобальную ситуацию, в том числе на энергетических рынках.

Позиция по Сирии у египетского руководства менялась. Если первоначально Каир пытался выступить в роли посредника, то затем М. Мурси, на фоне продолжавшихся уличных протестов, предпринял радикальные внешнеполитические шаги, которые убедили военных Египта, что он действует не в интересах страны. Вопреки заверениям, данным президенту России В. Путину в апреле 2013 года в ходе визита в Москву, нашедшим отражение в заявлении для прессы по итогам встречи (5), уже в июне М. Мурси выступил с радикальными утверждениями относительно необходимости смены режима в Сирийской Арабской Республике и своей готовности отправить в эту страну египетских военнослужащих и добровольцев.

Помимо того, что это заявление М. Мурси перечеркивало все договоренности относительно Сирии с президентом России В. Путиным, данная позиция нарушила давний принцип Египта, связанный с его дорогостоящим участием в гражданской войне в Йемене десятилетиями ранее: не вмешиваться в военном отношении против другой арабской страны (19). Воинственные заявления М. Мурси, очевидно, должны были подорвать доверие к нему со стороны руководства Российской Федерации.

Кроме того, в июне 2013 года президент М. Мурси фактически объявил войну Эфиопии во время телевизионного совещания по национальной безопасности под своим председательством, на котором открыто обсуждалась возможность нанесения военных ударов или проведения диверсионных операций против строящейся эфиопской плотины Возрождения, которая потенциально угрожала обеспечению водными ресурсами Египта (17).

Эти заявления касательно Сирии и Эфиопии подрывали национальную безопасность APE, и стало очевидным, что внешняя политика М. Мурси и его сторонников из числа «Братьевмусульман» вступила в прямое противоречие с национальными интересами страны. Ситуация усугублялась тем, что подобное поведение президента Египта было для него скорее характерным, чем исключительным явлением.

В апреле 2013 года во время визита в Судан М. Мурси выразил готовность уступить давно оспариваемую египетскую территорию Халаиб и Шалатин суданцам. После этого начальник штаба египетской армии С. Собхи посетил Судан и разъяснил, что Египет не ведет переговоры о сдаче какой-либо части территории. Этот инцидент вновь продемонстрировал военным, что «Братья-мусульмане» действуют против интересов национальной безопасности Египта.

М. Мурси подтолкнул Египет к международной изоляции и некоторыми другими ша- 
гами. Например, опираясь на исламистскую общность, он выступил против международной военной интервенции в Мали после того, как радикальные боевики-исламисты захватили значительную часть этого африканского государства. Данный шаг оставил Каир в изоляции в Африканском союзе.

Также, М. Мурси настоял на признании Косово, частично признанного государства с мусульманским большинством, вопреки советам аппарата безопасности. Кроме того, он потребовал освобождения осужденного террориста Шейха Омара Абдула Рахмана, сторонника радикального ислама, из тюрьмы в США. Кроме того, контакты М. Мурси с Пекином и Москвой могли иметь долгосрочные негативные последствия для стратегических отношений Египта с США, что подрывало интересы Египта (17).

Все это привело к государственному перевороту, по итогам которого 3 июля 2013 года М. Мурси был отстранен от власти. Между тем, уже к концу июня обстановка в стране стала выходить из-под контроля.

27 июня, на фоне продолжавшихся массовых протестов, М. Мурси выступил с обращением, в котором, в частности, заявил о намерении создать Высшую комиссию национального согласия для обсуждения новых поправок в Конституцию страны и одновременно поручил главе МВД создать специальный комитет для борьбы с «мародерами» (15).

На этом фоне в Египте продолжились столкновения противников и сторонников «Братьевмусульман», в ходе которых появились первые жертвы. Оппозиция требовала немедленной отставки М. Мурси и проведения новых досрочных президентских выборов.

30 июня, в годовщину президентства М. Мурси, оппозиция выдвинула ультиматум главе государства, в котором предоставила ему два дня на самостоятельный уход с поста президента, а в ночь с 30 июня на 1 июля протестующие штурмом овладели штаб-квартирой «Братьев-мусульман» в Каире.

1 июля 2013 года, в ответ на набирающее ход насильственное противостояние, армейское руководство Египта выступило с ультиматумом, в котором предоставило «политикам» 48 часов для урегулирования конфликтов, в противном случае непосредственным выходом из кризиса займутся военные, как и два года назад (15).

1 и 2 июля начались массовые отставки служащих системы государственного управления и членов правительства, в том числе министра иностранных дел и помощников президента. Еще пять министров ушли в отставку, в качестве причины заявив о несогласии с позицией президента М. Мурси (16).

Вечером 2 июля 2013 года М. Мурси обратился к армии с призывом отменить 48-часовой ультиматум, отверг возможность своего досрочного ухода, и обвинил в кризисе сторонников бывшего президента X. Мубарака. 3 июля он выступил с последним обращением в качестве президента. В нем М. Мурси выразил готовность создать новое коалиционное правительство, одной из главных задач которого будет организация новых парламентских выборов, а также независимую комиссию для внесения поправок в конституцию с учетом требований оппозиции, которые затем должен одобрить новый парламент страны (17).

Вечером 3 июля министр обороны Египта Абдельфаттах ас-Сиси выступил с телеобращением, в котором объявил о смещении М. Мурси, временной приостановке действия конституции и назначении председателя Конституционного суда 'Адли Мансура временно исполняющим обязанности президента. Все эти действия инициированы и осуществлены египетской армией (17).

Можно отметить, что данная ситуация во многом повторяла сценарий переворота 2011 года, когда на фоне протестов президент до самого конца предлагал все новые и новые компромиссы, отказываясь уступить главному требованию - немедленному ходу в отставку. Так же, как и в 2011 году, решающую роль в смене режима сыграла египетская армия.

На международном уровне вмешательство армии 3 июля 2013 года воспринималось иначе, чем 11 февраля 2011 года. В отличие от того, когда египетские военные вмешались, чтобы положить конец правлению Х. Мубарака, те же действия военных, произошедшие два с половиной года спустя, 3 июля 2013 года, против движения «Братьев-мусульман», США и ЕС, а также Африканский союз, встретили сдержанно и даже с осуждением, характеризуя их как государственный переворот (17).

В то же время, ряд стран, с которыми при президенте М. Мурси ухудшились отношения, поддержали его смещение. Так, сразу же после отставки М. Мурси Саудовская Аравия, Объединенные Арабские Эмираты и Кувейт обязались предоставить Египту в общей сложности 12 млрд. долл. США. Эти средства должны были сыграть существенную роль для египетской экономики: к началу переворота валютные резервы 
страны, находились на критически низком уровне - 14,9 млрд. долл. США. Они были выделены в виде прямых пожертвований, беспроцентных кредитов и поставок нефти.

\section{Заключение}

Проведённый анализ позволяет сформулировать следующие выводы.

Правление М. Мурси и «Братьев-мусульман» было относительно кратким, но весьма насыщенным периодом. В своем политическом курсе М. Мурси обычно руководствовался больше интересами организации «Братьев-мусульман», чем египетского общества или национальными интересами страны, что сказалось на принятой в 2012 году Конституции. Это привело к углублению кризиса и развитию нового витка конфликта в APE.

Нарастающие кризисные явления в египетском обществе носили комплексный характер и, как представляется, заключались в следующем:
- потеря М. Мурси и «Братьями-мусульманами» значительной части общественной поддержки;

- противодействие государственного аппарата и сил безопасности перестраиванию политической системы в духе идей движения «Братьевмусульман»;

- противостояние светской оппозиции;

- нарастание протестов, центром которых вновь, как и в 2011 году, стала площадь Тахрир в Каире;

- рост доверия к армии и ее особое положение в государстве и обществе.

Помимо этого, М. Мурси оказался неспособен решить социальные и экономические проблемы, а вместо этого попытался сосредоточить всю власть в своих руках.

Во внешней политике М. Мурси продемонстрировал слабое понимание национальных интересов, региональных и глобальных процессов, но проводил больше курс, характерный скорее для руководителя «Братьев-мусульман», а не Арабской Республики Египет.

\section{Литература}

Административный суд Египта отменил парламентские выборы. 17.06.2020. https://www.vesti.ru/doc.html?id=1049170

Арабский эксперт: египтяне против старого режима и «Братьев мусульман». 15 июня 2012. https://www.dw.com/ru/ арабский-эксперт-египтяне-против-старого-режима-и-братьев-мусульман/а-16029255

Верховный суд Египта призвал к роспуску парламента. 14 июня 2012. https://www.bbc.com/russian/international/2012/06/120614_egypt_court_parliament

Встреча с Президентом Египта Мухаммедом Мурси. Официальный сайт Кремля. 17.06.2020. http://kremlin.ru/events/ president/news/page/403

Заявления для прессы по итогам российско-египетских переговоров. Официальный сайт Кремля. 17.06.2020. http:// kremlin.ru/events/president/transcripts/page/202

Интервью президента Владимира Путина ежедневной египетской газете «Аль-Ахрам». Аль-Ахрам. 17.06.2020. http:// islam.ru/news/2015-09-04/38857

Клебер В., Варкентин А. В Египте избирали президента, а править будет фельдмаршал. 20 июня 2012. https://www. dw.com/ru/в-египте-избирали-президента-а-править-будет-фельдмаршал/a-16036573

Конституция Египта, декабрь 2012 года.17.06.2020.https://worldconstitutions.ru/?p=730

Лоай Мадхун. Комментарий: президенту Египта Мурси нужно добиваться примирения. 08.12.2012. https://www.dw.com/ ru/комментарий-президенту-египта-мурси-нужно-добиваться-примирения/a-16436551

Мохамед Абду Хассан Ахмед. Россия и Египет: курс на сближение. // Вестник Российского университета дружбы народов. Серия: Международные отношения. 2014. №3, С. 158-163.https://cyberleninka.ru/article/n/rossiya-i-egipet-kurs-nasblizhenie/viewer

Примаков Д. «Братская» конституция Египта. Российскийсоветпомеждународнымделам.11 февраля 2013 г. https://russiancouncil.ru/analytics-and-comments/analytics/bratskaya-konstitutsiya-egipta/

Ражбадинов М. Ассоциация «Братья-мусульмане» и перспективы политических процессов в современном Египте. // Вестник МГИМО Университета. - № 1, 2013. -С. $42-46$.

Ромашенко С. Египет аннулировал договор о поставке газа Израилю. 23.04.2012. https://www.dw.com/ru/eгипетаннулировал-договор-о-поставке-газа-израилю/а-15904043

Ромашенко С. Суд: Парламент Египта должен быть переизбран. 14 июня 2012. https://www.dw.com/ru/суд-парламентегипта-должен-быть-переизбран/а-16024775

Хроника переворота в Египте (2013 год). РИА Новости. 17.06.2020. https://ria.ru/20130815/956498419.html

Чиновники Египта массово уходят с постов. РИА Новости. 17.06.2020. https://ria.ru/20130701/946928575.html

Adel El-Adawy. Egypt's Evolving Foreign Policy. The Washington Institute.17.06.2020. https://www.washingtoninstitute.org/ policy-analysis/view/egypts-evolving-foreign-policy

Alaa Elhadidi. Egypt's Shifting Foreign Policy Priorities. The Cairo Review of Global Affairs. 17.06.2020. https://www.thecairoreview.com/essays/egypts-shifting-foreign-policy-priorities/ 
Brown N. Democratic Dilemma. Carnegie Endowment for International Peace. December 01, 2011. https://carnegieendowment. org/2011/12/01/muslim-brotherhood-s-democratic-dilemma/8kq

Controversial Articles in the 2012 Egyptian Constitution. Carnegie Endowment for International Peace. January 04, 2013. https://carnegieendowment.org/2013/01/04/controversial-articles-in-2012-egyptian-constitution-pub-54936

Egypt's Islamist parties win elections to parliament. 17June 2020.https://www.bbc.com/news/world-middle-east-16665748

Holger Albrecht. Egypt's 2012 Constitution. United States Institute of Peace. January 25, 2013. https://www.usip.org/sites/ default/files/PB139-Egypt's\%202012\%20Constitution.pdf

Presidential Election in Egypt Carter Center. May-June, 2012. https://www.cartercenter.org/resources/pdfs/news/peace_publications/election_reports/egypt-final-presidential-elections-2012.pdf

Ravinsky, J. Friends again? Saudi Arabia, UAE Jump in to Aid Egypt. The Cristian Science Monitor. 17.06.2020. https://www. csmonitor.com/World/Global-Issues/2013/0710/Friends-again-Saudi-Arabia-UAE-jump-in-to-aid-Egypt

Schenker D. Arab Spring or Islamist Winter? World Affairs Journal. January/February 2012, 17.06.2020. https://www.washingtoninstitute.org/policy-analysis/view/arab-spring-or-islamist-winter

Stein E. After the Arab Spring: power shift in the Middle East? London School of Economics and Political Science, London, UK. May, 2012. https://core.ac.uk/download/pdf/2800214.pdf

\section{References}

Adel El-Adawy. Egypt's Evolving Foreign Policy. The Washington Institute.17.06.2020. https://www.washingtoninstitute.org/ policy-analysis/view/egypts-evolving-foreign-policy

Admenistrativniy sud Egipta otmenil parlamentskiye vibori. 17.06.2020. https://www.vesti.ru/doc.html?id=1049170

Alaa Elhadidi. Egypt's Shifting Foreign Policy Priorities. The Cairo Review of Global Affairs. 17.06.2020. https://www.thecairoreview.com/essays/egypts-shifting-foreign-policy-priorities/

Arabskiy ekspert: egiptyane protiv starogo rejima I "Brat'yev musul'man". 15 june 2012. https://www.dw.com/ru/arabskiyekspert-egiptyane-protiv-starogo-rejima-i-brat'yev-musul'man/a-16029255

Brown N. Democratic Dilemma. Carnegie Endowment for International Peace. December 01, 2011. https://carnegieendowment. org/2011/12/01/muslim-brotherhood-s-democratic-dilemma/8kqi

Chinovniki Egipta massovo uhodyat s postov. RIA Novosti. 17.06.2020. https://ria.ru/20130701/946928575.html

Constitution of Egypt, December 2012 year. 17.06.2020.https://worldconstitutions.ru/?p=730

Controversial Articles in the 2012 Egyptian Constitution. Carnegie Endowment for International Peace. January 04, 2013. https://carnegieendowment.org/2013/01/04/controversial-articles-in-2012-egyptian-constitution-pub-54936

Egypt's Islamist parties win elections to parliament. 17June 2020.https://www.bbc.com/news/world-middle-east-16665748

Holger Albrecht. Egypt's 2012 Constitution. United States Institute of Peace. January 25, 2013. https://www.usip.org/sites/ default/files/PB139-Egypt's\%202012\%20Constitution.pdf

Hronika perevorota v Egipte (2013). RIA Novosti. 17.06.2020. https://ria.ru/20130815/956498419.html

Intervyu prezidenta Vladimira Putina ejednevnoy egipetskoy gazete :Al'-Ahram”. 17.06.2020. http://islam.ru/news/2015-09$04 / 38857$

Kleber B., Varkentin A. V Egipte izbirali prezidenta, a pravit' budet fel'dmarshal. 20june 2012. https://www.dw.com/ru/Bегипте-избирали-президента-а-править-будет-фельдмаршал/а-16036573

Lyuay Madhun. Kommentariy: prezidentu Egipta Morsi nujno dobivat'sya primereniya. 08.12.2012. https://www.dw.com/ru/ kommentariy-prezidentu-egipta-morsi-nujno-dobivat'sya-primereniya/a-16436551

Mohamed Abdu Hassan Ahmed. (2014). Rossiya I Egipet: kurs na sblijeniye. [Russia and Egypt: a course for rapprochement.]. // VestnikRossiyskogo universiteta drujbi narodov. Seriya: Mejdunarodniye otnosheniya. No3, C. 158-163.https://cyberleninka.ru/ article/n/rossiya-i-egipet-kurs-na-sblizhenie/viewer

Presidential Election in Egypt Carter Center. May-June, 2012. https://www.cartercenter.org/resources/pdfs/news/peace_publications/election reports/egypt-final-presidential-elections-2012.pdf

Primakov D. "Bratskaya" konstitutsiya Egipta. ["Fraternal" constitution of Egypt]. Rossiyskiy sovet po mejdunarodnim delam. 11 february 2013 y. https://russiancouncil.ru/analytics-and-comments/analytics/bratskaya-konstitutsiya-egipta/

Radjbadinov M. (2013) Assotsiatsiya "Brat'yev musul'man" I perspektivi politicheskih voprosov v sovremennom Egipte [Association "Muslim Brothers" And the prospects of political issues in modern Egypt] // Vestnik MGIMO Universiteta. No 1. C. $42-$ 46.C. 44.

Ravinsky, J. Friends again? Saudi Arabia, UAE Jump in to Aid Egypt. The Cristian Science Monitor. 17.06.2020. https://www. csmonitor.com/World/Global-Issues/2013/0710/Friends-again-Saudi-Arabia-UAE-jump-in-to-aid-Egypt

Romashenko S. Sud: Parlament egipta doljen bit' pereizbran. 14 june 2012. https://www.dw.com/ru/sud-parlament-egiptadoljen-bit'-pereizbran/a-16024775

Romashenko S. Egipet annuliroval dogovor o postavke gaza Izrailyu. 23.04.2012. https://www.dw.com/ru/ egipet-annulirovaldogovor-o-postavke-gaza-izrailyu /a-15904043

Schenker D. Arab Spring or Islamist Winter? World Affairs Journal. January/February 2012, 17.06.2020. https://www.washingtoninstitute.org/policy-analysis/view/arab-spring-or-islamist-winter

Stein E. After the Arab Spring: power shift in the Middle East? London School of Economics and Political Science, London, UK. May, 2012. https://core.ac.uk/download/pdf/2800214.pdf

Verhovniy sud Egipta prizval k rosrusku parlamenta. 14 june 2012. https://www.bbc.com/russian/international/2012/06/120614_ egypt court parliament

Vstrecha s Prezidentom Egipta Muhammedom Morsi. Ofitsial'niy sayt Kremlya. 17.06.2020. http://kremlin.ru/events/president/ news/page/403

Zayavleniya dlya pressi po itogam rossiysko-egipetskih peregovorov. Ofitsial'niy sayt Kremlya. 17.06.2020. http://kremlin.ru/ events/president/transcripts/page/202 